\title{
The Quality of Income Planning for County Budgets vs. Multi-annual Financial Forecast
}

\author{
Małgorzata GAŁECKA \\ Wroclaw University of Economics, Wroclaw, Poland \\ malgorzata.galecka@ue.wroc.pl
}

\begin{abstract}
Planning pertains to any functioning unit of both the public and the private sector. Such planning forces the search for newer and newer forecasting techniques and optimal presentation of data. Public finance sector institutions actively use the instruments and tools specific to private sector entities. For that purpose, in all local self-government units Multiannual Financial Forecast is developed. Using it, the authorities of local self-government units should design the content of future budgets, anticipate their result, specify the exact level of certain expenditure categories and consequently the spending limits for projects.

The objective of this article is to assess the quality of county budget income planning in the context of MAFF functioning. The author is of the opinion that any realistic estimate of potential income determines the possibilities for a more effective implementation of public tasks. The quality of income planning is a starting point for the long-term planning in a given self-government unit. The study has shown that in the period of the MAFF operation, the accuracy of forecasts in the respective rural counties improved.
\end{abstract}

Keywords: Quality of Planning, Public Income, Local Self-government, Multiannual Financial Forecast.

\section{Introduction}

Financial planning is perceived as a process that determines the means of achieving financial objectives. [5] This process includes many elements, including primarily forecasting, programming and plan development. [6] Schick A. indicates that planning should enable financing of local self-government unit (LSGU) activities in terms of on-going processes having their financial consequences in the future so as to ensure the stability of the financial economy as well as the effectiveness and efficiency of the current and development-related decisions taken. [15] For that purpose, in all LSGU annual plans and long-term plans are developed. Fiscal rules, which underpin the development of decisions to disburse public financial resources and verify their legitimacy on the basis of the applicable laws and regulations, are closely linked to the annual plan. The budget, in view of the need to adopt it and then implement it according to specific procedures and legal standards has very limited 
possibilities as a development instrument. Among these limitations, e.g. the planning period can be indicated. It must relate to a period of one budgetary year. The process of budget development adoption and implementation comply with the applicable rules of law. All this contributes to very little flexibility of such budget. The budget is a good tool for implementation of current activities, whereas it seems to be too "short" for investment financing. At this point, it is necessary to link the budget with longterm financial or investment plans. In this way, the budget operates not only as a plan of current tasks, but also as an instrument to implement strategic tasks. [1] Also, the large variability of economic processes and financial markets present in recent years has shown insufficient efficiency of using the budget as a tool of financial planning. [2] Planning and plans are the classic and basic institutions, without which the modern state cannot function so that its activities were considered measurable and predictable. Since 2011 the multi-annual financial forecast (MAFF) and a long-term financial plan have been the strategic documents functioning together with the budget. The former is addressed to the local self-government and the latter to the state sector. These documents are of a similar internal structure and should serve to assess the long-term potential of public finance. MAFF combines many planning processes taking place in the unit: planning, spatial development, financial planning, strategic planning of unit development and investment planning. In practice, MAFF is a combination of planning documents already operating in local self-governments, including e.g.: a long-term investment plan, spending limits on programs and projects implemented from the EU funds, non-repayable aid of the EFTA countries and the forecasts of debt amount. The task of the forecast is to raise the level of transparency and openness of local self-government activities and to assess the financial standing and credit rating. [12] The substantive scope of MAFF was specified by the act on public finance. [13] Article 226 of this act specifies the elements that should be indicated in MAFF in each year covered by the forecast. These components are linked in a specific way to the so-called long-term forecast for budgets (income and expenditure) which forms the first of the annexes to the resolution on MAFF. The analysis of the legal provisions of law on public finance provides the basis to find that the status of MAFF is equivalent to the one held by a budget resolution. In view of the above, in the literature certain doubts arise: Does the budget reflect the provisions of MAFF or is the long-term plan subject to the adopted local self-government budget? [16]

MAFF is to be an instrument for better planning and implementation of income and expenditure, which should result in a significant reduction of expenditure and consequently of debt incurred by LSGU. Using MAFF, the authorities of LSGU should design the content of future budgets, anticipate their result, specify the exact level of certain expenditure categories and consequently the spending limits for projects. The adopted planning values in terms of income, expenses, revenue and expenditure have a strong relationship with the sphere of public task implementation. 
The only question is whether a given LSGU attempts to capture this relationship during its works on MAFF. This situation could lead to a clear dilemma which, in practice, is seen in the application of the provisions on MAFF - whether it is an important instrument used when making strategic decisions? Does it boil down to the role of a spreadsheet, drawn up because of the formal requirements and the need to obtain the opinion of financial management supervisory authorities? In Polish literature, these issues have been raised many times and there are divided opinions about it. After the first year of MAFF application, there was an opinion that it is not an ideal planning and management document. The legal provisions regarding MAFF were evaluated as imprecise. Many doubts were raised by: the realism of data, compliance of MAFF with the budget resolution, the powers of LSGU in terms of various changes in the course of the financial year and issues related to the list of projects. Most authors and practitioners agree however that the introduction of a document of a similar nature is necessary. MAFF drawn up diligently, fairly realistic and made with the use of macroeconomic indicators, can become a document that facilitates budget income and expenditure planning and enables the assessment of the financial standing in LSGU. The most important, however, is the manner of perceiving MAFF by the authorities of LSGU in practical terms and not as a statutory requirement.

\section{Methods}

As part of this article, the author focused on issues related to the effectiveness of income planning for LSGU. The author is of the opinion that any realistic estimate of potential income determines the possibilities for a more effective implementation of public tasks. The quality of income planning is a starting point for the long-term planning in a given self-government unit. The objective of this article is to assess the quality of county budget income planning in the context of MAFF functioning. The author poses a hypothesis that the requirement of using the multi-annual financial forecast did not improve the quality of planning the rural county budget income.

Data connected with the size of planned income, its components and the actual income were analyzed. The comparison of the expected basic macroeconomic indicators with their actual values was considered the starting point of the analysis. These indicators are the basis for estimating the budget-related income that is essential for counties.

The study covered the period between 2007 and 2016, i.e. the years in which the budgetary planning was carried out without MAFF and the years in which MAFF was actually applied. The results of the investigation are based on two periods of investigation. The first one pertains to the years in which MAFF did not function (2007-2011). The second period of the study covers the years of the actual 
functioning of the forecast - i.e. 2012-2016. The object of research are all rural counties of Lower Silesian province (26 rural counties).

The selected results of empirical research over the quality of budgetary planning presented in this paper were limited to the area of income. The statistical data relating to the plan and income achieved by LSGU have been obtained from the Regional Chamber of Auditors for Lower Silesia province - the quarterly statements of budget implementation of LSGU for 2007-2016 (plan as at the end of the first quarter and implementation as at the end of the fourth quarter).

The data on the projected values of macroeconomic indicators come from the document "Assumptions for the draft state budget 2007-2016 adopted by the Council of Ministers". To show the actual value of indicators the database of the Central Statistical Office was used.

The data on projected budget income came from the annual budget acts for individual years, while information on the obtained income was taken from reports on the implementation of the state budget for individual years.

The considerations and analyses presented in the article refer to the previous research results on MAFF operation published by the author and are the starting point for the next deliberations relating to MAFF effectiveness with regard to the assessment of the accuracy of income and expenditure forecasts for LSGU.

The cross-analysis of variables enables the assessment of mean errors for the investigated variables for the objects in question. To determine the error for the entire group that the author is investigating, mean percentage error for forecasts (MPE) has been applied. To achieve the perfect matching of plans and implementation, this value should be equal to zero or should be very low - when the value of ME indicator is positive, forecasts are underestimated, and when it is negative, forecasts are overestimated.

$$
M P E=\frac{1}{n} \sum_{t=1}^{n}\left(\frac{\left(y_{t}-y_{t p}\right)}{y_{t}}\right) * 100
$$

where: $Y_{t}$ - actual value of variable in time " $t$ " (implementation)

$Y_{t p}$ - projected value of variable in time "t" (plan).

Most textbooks recommend the use of the mean absolute percentage error (MAPE). $[4,7,9,10]$ MAPE informs us of the mean value of forecast errors for a given period, expressed in percentage. It indicates the percentage of error that such forecast is subject to [11].

$$
M A P E=\frac{1}{n} \sum_{t=1}^{n} \frac{\left|y_{t}-y_{t p}\right|}{y_{t}}
$$


On the basis of MAPE indicator, the forecasting accuracy indicator (TFA) may be introduced.

\section{Results}

As part of the basic budget-related income sources of county self-government units there are fundamental limitations to their forecasting. At this point, a relatively limited role of the local self-governments in forecasting the budget income based on participation in personal income tax (hereinafter: PIT), targeted subsidy or general subsidy should be emphasized. Annual amounts of the subsidy and funds from participation in PIT for individual counties are determined by the ministry of finance. The value of income planned due to participation in PIT results e.g. from the participation rate of PIT due for a given county. The proceeds depend also on the value of the macro-economic indicators assumed in the draft state budget for a given financial year. In addition, information on the proceeds from the source that is so vital for any county, is not obligatory, but generated only for the purposes of providing information and estimation. This results from the fact that tax income is planned in the state budget on the basis of estimates and forecasts. The implementation of income may therefore be increased or decreased.

The basis for obtaining an individual part of the general subsidy is the necessity to meet the conditions set out in the relevant algorithm. The law on LSGU income specifies in detail what data are the basis of the algorithm. Consequently, the level of a particular part (or amounts) of subsidy is determined on the basis of a mathematical model (on the basis of ex-post data) and is demandable. Therefore, the accuracy of income forecasts from this source is very high.

Significant variation of forecast accuracy and at the same time of the planning quality occurs in the case of income from participation in income tax, other own income and subsidies. In the first case, these differences may arise primarily from discrepancies between the forecasts of macroeconomic indicators taken into account by the central sector and the values of these indicators characteristic for individual counties. Significant underestimation or overestimation when predicting the size of macroeconomic values may affect the quality of budgetary planning.

The basis of the structure and forecast of the income and expenditure for the LSGU budget is constituted by internal regulations in addition to the existing legislation, including the resolution of county councils (municipalities, provincial parliament) concerning the adoption of the multi-annual financial forecast for a given unit and he assumptions of the draft state budget for a given year adopted by the Council of Ministers, where basic macroeconomic indicators are determined. [13, 14]

The subject of the comparison of basic macroeconomic indicators was GDP indicator, price growth index and the unemployment rate. The analysis covered the effective planning of total income for the state budget taking into account the 
proceeds due to PIT and CIT. The author has decided to examine the forecast accuracy indicator for the subsidies awarded to the counties from the state budget due to implementation of the government administration tasks and other tasks delegated to LSGU. Forecast accuracy determines the quality of planning individual components of the budget-related income. The results of the studies are presented in the table below.

Table 1. MAPE of macroeconomic indicators and state budget, \%. Source: Own elaboration.

\begin{tabular}{|c|c|c|c|c|c|c|c|c|}
\hline & GDP & $\begin{array}{c}\text { Price } \\
\text { growth } \\
\text { index }\end{array}$ & $\begin{array}{c}\text { Un- } \\
\text { empl. } \\
\text { rate }\end{array}$ & $\begin{array}{c}\text { State } \\
\text { budget } \\
\text { income }\end{array}$ & CIT & PIT & Subsidies & $\begin{array}{c}\text { PIT \& } \\
\text { CIT }\end{array}$ \\
\hline 2007 & 34.3 & 24.0 & 25.9 & 3.1 & 10.1 & 10.6 & 7.0 & 10.4 \\
\hline 2008 & 35.7 & 45.2 & 4.2 & 11.2 & 0.0 & 6.5 & 9.7 & 3.8 \\
\hline 2009 & 78.6 & 17.1 & 33.1 & 10.5 & 0.6 & 4.0 & 8.0 & 2.6 \\
\hline 2010 & 66.7 & 61.5 & 3.2 & 0.5 & 20.8 & 1.4 & 7.1 & 8.8 \\
\hline 2011 & 30.0 & 46.5 & 20.8 & 1.6 & 0.2 & 0.3 & 6.9 & 0.1 \\
\hline 2012 & 150.0 & 24.3 & 25.4 & 2.1 & 5.9 & 1.1 & 27.9 & 3.0 \\
\hline 2013 & 107.1 & 200.0 & 7.5 & 7.2 & 4.7 & 0.9 & 8.7 & 2.3 \\
\hline 2014 & 24.2 & 240.0 & 20.0 & 2.0 & 0.1 & 1.6 & 3.1 & 1.0 \\
\hline 2015 & 0.0 & -355.6 & 25.8 & 2.8 & 0.8 & 0.0 & 2.1 & 0.3 \\
\hline & -383.3 & 18.1 & 0.3 & 1.2 & 2.8 & 10.7 & 2.2 \\
\hline
\end{tabular}

The results of the analysis show systematic and random errors made in the process of planning the state budget. The most serious errors were made when planning the GDP and inflation rate. For these indicators, it is difficult to talk about errors, the presented forecasts were simply completely inaccurate. This can be seen especially well in 2012-2013 (as regards GDP) and in 2013-2016 (as for inflation). In 2015 only the GDP forecast was $100 \%$ accurate (see table 1). 
Numerous variations in the accuracy of macroeconomic indicator forecasts show that during the last few years, budget planning required extreme caution. The turbulence on the financial markets has resulted e.g. in violent disturbances in the public finance. In such a situation, the process in planning fiscal aggregates is extremely difficult and complex.

Table 2. MAPE of counties income forecast and forecast accuracy (TFA), \%. Source: Own elaboration.

\begin{tabular}{|c|c|c|c|c|c|c|c|c|}
\hline & \multicolumn{2}{|c|}{ Total income } & \multicolumn{2}{c|}{ Own income } & \multicolumn{2}{c|}{$\begin{array}{r}\text { Participation in } \\
\text { Pit \& Cit }\end{array}$} & \multicolumn{2}{c|}{ Subsidies } \\
\hline & MAPE & TFA & MAPE & TFA & MAPE & TFA & MAPE & TFA \\
\hline $\mathbf{2 0 0 7}$ & 9.1 & 90.9 & 15.4 & 84.6 & 8.9 & 91.1 & 14.4 & 85.6 \\
\hline $\mathbf{2 0 0 8}$ & 12.6 & 87.4 & 18.3 & 81.7 & 10.4 & 89.6 & 26.7 & 73.3 \\
\hline $\mathbf{2 0 0 9}$ & 6.7 & 93.3 & 23.9 & 76.1 & 10.3 & 89.7 & 22.0 & 78.0 \\
\hline $\mathbf{2 0 1 0}$ & 11.5 & 88.5 & 26.8 & 73.2 & 3.0 & 97.0 & 21.6 & 78.4 \\
\hline $\mathbf{2 0 1 1}$ & 11.8 & 88.2 & 8.7 & 91.3 & 5.0 & 95.0 & 26.8 & 73.2 \\
\hline $\mathbf{2 0 1 2}$ & 6.0 & 94.0 & 10.7 & 89.3 & 4.6 & 95.4 & 15.7 & 84.3 \\
\hline $\mathbf{2 0 1 3}$ & 5.0 & 95.0 & 11.5 & 88.5 & 4.8 & 95.2 & 12.4 & 87.6 \\
\hline $\mathbf{2 0 1 4}$ & 5.1 & 94.9 & 10.3 & 89.7 & 0.9 & 99.1 & 13.0 & 87.0 \\
\hline & 6.1 & 94.9 & 12.1 & 87.9 & 2.3 & 97.7 & 9.0 & 91.0 \\
\hline & 93.9 & 7.8 & 92.2 & 4.0 & 96.0 & 15.9 & 84.1 \\
\hline
\end{tabular}

The financing system of county-level LSGU is based on the subsidies, subsidies from the state budget and own income. The accuracy of income forecasts for respective counties of Lower Silesian province is varied. In all investigated counties, both the phenomenon of income overestimation and underestimation was present. The 
essential differences between implementation and plans occurred mainly in total income, including: subsidies, own income and income from participation in income tax. The investigation enabled its author to observe the improved quality of income planning in rural counties of Lower Silesian province. A difference between the indicators (MAPE and TFA) is noticeable in the period 2007-2011 and 2012-2016 (see table 2).

Table 3. Forecast estimation indicator (MPE) in relation to implementation of counties income. Source: Own elaboration.

\begin{tabular}{|c|c|c|c|c|c|}
\hline & Total income & Own income & $\begin{array}{l}\text { Participation } \\
\text { in Pit \& Cit }\end{array}$ & Subsidies & $\begin{array}{c}\text { General } \\
\text { subsidies }\end{array}$ \\
\hline 2007 & 4.7 & 2.2 & 8.9 & 12.8 & 2.6 \\
\hline 2008 & 5.8 & -1.1 & 10.4 & 21.2 & 3.4 \\
\hline 2009 & -1.6 & -20.9 & -9.4 & 14.6 & 1.5 \\
\hline 2010 & 1.2 & -22.1 & -1.1 & 15.5 & 2.8 \\
\hline 2011 & 7.0 & -1.4 & 3.9 & 14.5 & 1.8 \\
\hline 2012 & 1.9 & -3.4 & -2.7 & 3.7 & 0.3 \\
\hline 2013 & 0.4 & -6.5 & -3.3 & 4.5 & 1.5 \\
\hline 2014 & 2.4 & -1.3 & -0.4 & 7.1 & 0.7 \\
\hline 2015 & -1.7 & -4.6 & 0.3 & -2.9 & 0.5 \\
\hline 2016 & 1.6 & 2.5 & 0.2 & 1.7 & 1.3 \\
\hline
\end{tabular}

As indicated above, the significant differences in the accuracy of rural county forecasts occurred in their total income. This was mainly due to changes in own income and the size of income received due to subsidies. Diversification in the sources of income may have a positive impact on the growth of effectiveness in planning their total budget income. This is reflected by the situation that occurred in 2009 or 2010 , when the lower than planned own income was accompanied by the use 
of the subsidies that were higher than expected. Finally, the effectiveness of total income forecasts for LSGU increased as compared to previous years.

MAPE indicator for counties of Lower Silesian province in 2007 was 9\%, in 2008 it reached the maximum value of $12.6 \%$. This means that in 2008 the implementation of income differed from the forecasts by $12.6 \%$. From 2012 significant improvement of this indicator (approx. 5-6\%) is visible. In the last year of the investigation its value increased to $6.1 \%$, but still it is substantially lower than in 2007-2011. In other words, forecast accuracy in the years 2012-2016 has been improved and on average it was $94.6 \%$ (2007-2011 - 89.6\% on average). This means that during the functioning of MAFF, forecasts differed from the actual values by $5.4 \%$ on average. On the basis of Fig.1. the improvement of data distribution for the investigated feature can be observed. The values of estimation indicator in individual years are varied, but a small decreasing trend for the investigated indicator is noticeable. A decrease in the number of counties with underestimation or overestimation of total income exceeding $10 \%$ can be found.

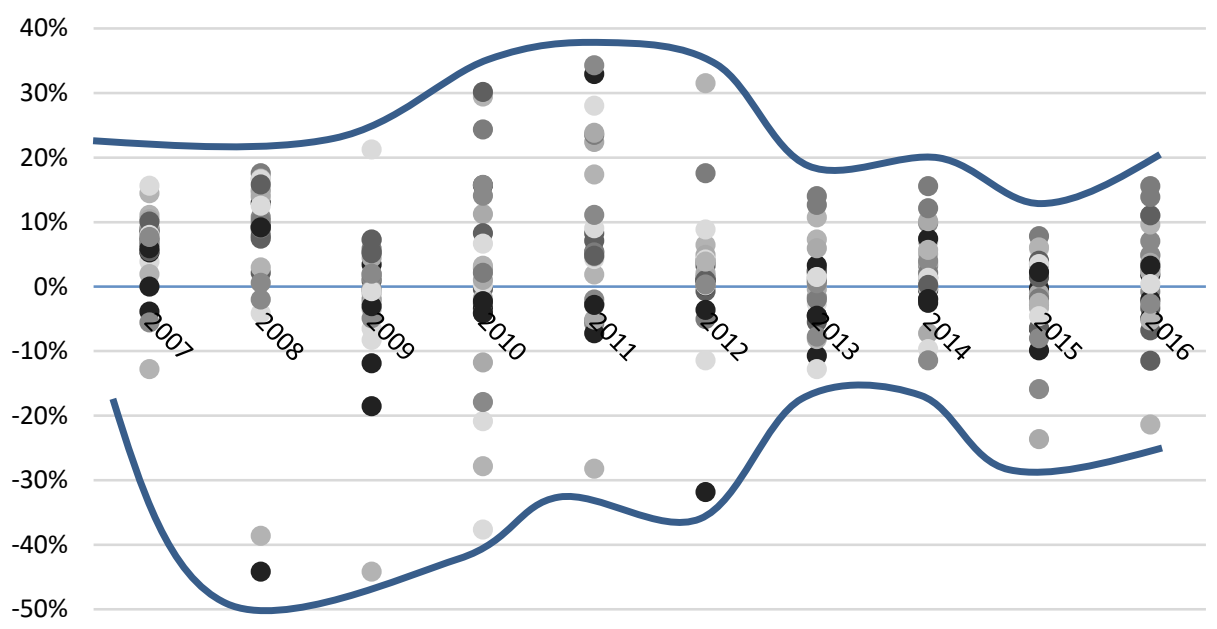

Fig. 1. The values of estimation indicator of total income in individual counties of Lower Silesian province, 2007-2016.

Significant deviations of the forecast from the income actually implemented occurred in terms of targeted subsidies. Taking into account the arbitrary nature of granting the subsidies from the state budget, in principle, this seems to be understandable. The targeted subsidy is used for the purpose of implementing the tasks carried out by county services, inspections and guards. Counties may obtain targeted subsidies for financing their own current and financial tasks (e.g. in the area of social assistance). Among the subsidy-related income, the following grants should also be mentioned: subsidies to implement the tasks performed by way of contracts and agreements between LSGU and external subsidies and funds to finance the expenditure and 
execution of financial tasks with the participation of EU funds. The highest share among the so-called subsidy income is covered by targeted subsidies for commissioned tasks and financing own tasks. When examining the share of these subsidies in the total budgets in LSGU, the highest one appears to occur in rural counties. [8]

The information on the final amounts of subsidies from the state budget is provided to local self-governments after the adoption and announcement of the budget act for a given year. Taking into account the lasting nature of the tasks commissioned to counties by central administration, it appears that the level of income derived from this source should be reasonably stable in subsequent years. Nothing could be further from the truth. Research indicates that the accuracy of income forecasts for the subsidy-related income of rural counties is very diverse. In 2007, the value of mean forecast error was $14.4 \%$, in subsequent years it increased only to reach $26 \%$ in 2011. Since 2012 onwards the quality of subsidy income forecasts for rural counties of Lower Silesia province has improved. In 2012 the value of MAPE was at the level of $15.7 \%$, in 2015 it declined to $8.9 \%$. In the last year of the investigation it rose again to $15.9 \%$.

As regards the income coming from subsidies, a trend to underestimate forecasts is noticeable (see table 3). To a large extent this is due to the numerous changes in the state budget during its implementation. The main factors affecting the final amounts of the subsidies include e.g.: resignation or repayment of unused funds, savings or allocation of reserves. Any additional funds in the budget give room for the possibility of increasing the amount of granted subsidies. This trend is particularly noticeable in 2007-2011 and in 2014 - 2016. After 2011 the level of underestimation of income coming from subsidies decreased considerably. This trend was accompanied by the increase in the number of counties with overestimation of subsidy-related income forecasts. These changes resulted from a substantial decrease in total subsidies in relation to the previous year for all counties (in 2012 by $17.8 \%$, and in 2015 by $7.6 \%$.).

Optimistic assumptions about the planned income were made in terms of the county's own income. This phenomenon is particularly visible in 2007-2010. The changes in PIT had a major impact on the quality of own income forecasts in 20082010. These changes pertained to e.g. the "unfreezing" of tax thresholds or replacing a three-point PIT scale with a new one having two reduced rates. As for the quality of income planning based on CIT, the impact of the economic crisis on the increased instability of this source of income is of particular importance. Since 2011, MAPE indicator has improved and has not exceeded $5 \%$ for the entire period of investigation. Generally, the income from participation in income taxes, especially in CIT, is considered to be most unstable. Although, as for rural (and municipal) counties, such income is considered more stable (in relation to others) and more important in terms of profitability (than in the case of municipalities). [3] 


\section{Conclusion}

The analysis of data from 2007-2016 indicates a discrepancy between the level of errors for expected macroeconomic indicators and the quality of planned income of the state budget. The studies have shown the lower quality of state budget income planning in the first period of investigation (with qualitatively better planning of macroeconomic indicators). In the second period of investigation, despite the huge errors in planning the indicators, the quality of income is planning improved. It should be noted that since 2011 in the "state budget" a multi-annual financial plan has been applied. The exception are the years in which fundamental changes were introduced in personal income tax. Despite this discrepancy, a trend to transfer errors in macroeconomic indicator forecasts to state budget income forecasts is noticeable. Another explanation of this discrepancy is the time delay regarding the effects of better/worse economic conditions for the budget income.

The quality of state budget income forecasts affected the quality of planning the counties' income. In 2007-2011 the quality of planning the counties' income was characterized by a substantially larger error than in 2012-2016. As regards the subsidies and general subsidies for the analyzed counties throughout the entire period of investigation, the planned values were underestimated. It can be concluded that there was the so-called pessimistic forecasting. Since 2012, a significant improvement has been noticed in relation to the quality of planning, especially with regard to the subsidy-related income. Optimistic forecasting, i.e. overestimation, is occurred when planning own income (see table 3 ).

The study has shown that in the period of the MAFF operation, the accuracy of forecasts in the respective rural counties of Lower Silesian province improved. This is reflected in the mean forecast error indicator that had significantly better results in 2012-2016 than in 2007-2011. The estimated values of income were still erroneous, but on the basis of estimation indicator a considerable improvement of its parameters can be noticed. Local self-government units, when preparing MAFF, plan their income, and consequently the public expenditure, more carefully. Perhaps this should be attributable only to a desire to meet such statutory requirements as the limitation of the amount of debt repayment so as not to be contested by the Regional Chamber of Auditors. Yet, it seems to be an unquestionable thing that the level of planning quality (and thus the forecast accuracy) in the period of the MAFF operation improved significantly. This can be seen with regard to planning the total income, primarily including own income, participation in central taxes and income from subsidies.

The improvement of the investigated parameters is indirectly affected also by other elements: improvement of planning quality for macro-economic indicators, changes in the law, the economic situation in the country or the introduction of innovative management methods (e.g. task-oriented budget). In a given period of time, in addition to introducing MAFF, self-government units were not obliged to implement other forms/methods of budget planning. The theory saying that the redundancy of legal regulations present for many years and their ambiguity or different types of problems associated with the practicability of planning suddenly forced the authorities of rural counties in Lower Silesian province to increase the detailedness regarding 
verification of the planned budget income is also questionable. On this basis, it can be concluded that the performance of the multi-annual financial forecast affected the quality of income planning for rural counties of the Lower Silesian province in a positive manner. Thus, the hypothesis made by the author was rejected. However, the author does not risk a generalization of a positive impact of MAFF on the quality of planning in all LSGU. A more extensive investigation covering essentially all subsectors of local self-government units is necessary.

Acknowledgement. Scientific grants MNiSW for the young researchers, project:

Measurement of public expenditure efficiency in public and private sector institutions.

\section{References}

1. Adamiak, J.: Dług publiczny sektora finansów samorządu terytorialnego w Polsce po akcesji do Unii Europejskiej. In: Dylematy i wyzwania finansów publicznych, pp. 299. Wydawnictwo UE Poznań, Poznań 2010.

2. Adamiak, J.: Wieloletnia prognoza finansowa jako narzędzie zarzadzania finansami lokalnymi. In: Finanse Komunalne, vol 1-2, pp.73. Wolters Kluwer (2012).

3. Będziszak, M.: Stabilność dochodów własnych bieżących jednostek samorządu terytorialnego w Polsce. In: Finanse komunalne, vol. 3, pp. s. 23. Wolters Kluwer (2017).

4. Bowerman, B.L, O’Connell, R.T., Koehler, A.B.: Forecasting, time series and regression: an applied approach, pp.18. Thomson Brooks/Cole: Belmont, CA (2004).

5. Chase, R.B, Aquilano, N.J., Jacobs F.R.: Production and Operations Management, Manufacturing and Services, McGraw-Hill Companies, USA. (1998).

6. Chrostowski, A., Szczepankowski P.: Planowanie. In: Koźmiński A., Piotrowski. W. (eds.) Zarządzanie. Teoria i praktyka, pp. 182. PWN, Warszawa (2002).

7. Galiński, P.: Jakość planowania budżetu w jednostkach samorządu terytorialnego w Polsce. In: Finanse Komunalne, vol.10, pp. 39. Wolters Kluwer (2013).

8. Gałecka, M.: Struktura i poziom dotacji celowych w dochodach samorządu terytorialnego, Zarządzanie i Finanse, vol. 2/3, pp. 95. Uniwersytet Gdański, Gdańsk (2013).

9. Hanke, J.E., Reitsch, A.G.: Business forecasting, Journal of the Royal Statistical Society. Series D (The Statistican) vol. 38, no. 1, pp. 79. Wiley (1989), DOI: 10.2307/2349022

10. Hanke, J.E., Reitsch, A.G.: Business forecasting, 5th ed., pp.120. Englewood Cliffs, NJ: Prentice Hall (1995).

11. Hydman, R.J., Koehler, A.B.: Another look at Measures of Forecast Accuracy, International Journal of Forecasting 22(4), 679-688, (2006), DOI: 10.1016/j.ijforecast.2006.03.001

12. Krajewska, M., Jońca, A.: Wieloletnia prognoza finansowa jako instrument zarządzania gospodarką finansową jednostek samorządu terytorialnego - podsumowanie dwóch lat doświadczeń, In: Finanse Komunalne, vol. 11 pp. 35. Wolters Kluwer (2012).

13. Polish legal act. Ustawa z dnia 27 sierpnia 2009 r. o finansach publicznych Dz. U. 2009, Nr 157, poz. 1240

14. Polish legal act. Ustawa z dnia 13 listopada 2013 r. o dochodach jednostek samorządu terytorialnego Dz. U. 2003, Nr 203, poz. 198.

15. Schick, A.: Performance Budgeting and Accrual Budgeting: Decision Rules or Analytic Tools? OECD Journal on Budgeting 7(2)., s.112 (2007), DOI:10.1787.16812336.

16. Walczak, P.: Wieloletnia Prognoza Finansowa. Beck (2015). 